\title{
Hu Angang, China in 2020: A New Type of Superpower,
} Washington D.C., Brookings Institution Press, 2011, 213 pp.

\section{Maoliang Bu}

\section{OpenEdition \\ Journals}

\section{Electronic version}

URL: http://journals.openedition.org/chinaperspectives/6810

DOI: 10.4000/chinaperspectives.6810

ISSN: 1996-4617

\section{Publisher}

Centre d'étude français sur la Chine contemporaine

\section{Printed version}

Date of publication: 1 September 2015

Number of pages: $59-60$

ISSN: 2070-3449

Electronic reference

Maoliang Bu, "Hu Angang, China in 2020: A New Type of Superpower, », China Perspectives [Online], 2015/3 | 2015, Online since 01 January 2017, connection on 22 September 2020. URL : http:// journals.openedition.org/chinaperspectives/6810; DOI : https://doi.org/10.4000/chinaperspectives. 6810 
through numerous multilateral initiatives, from the United Nations General Assembly to ICANN (Internet Corporation for Assigned Names and Numbers), not to mention APEC (Asia-Pacific Economic Cooperation).

In the last chapter, Austin explains that the digital domain is not an issue of public policy like the others. In his view, the adoption of information technologies should lead to thorough changes in the regime, perhaps like Singapore, deemed a model single-party regime that has succeeded in putting in place a modern information society (which I see as a problematic assertion, given the limits on free expression in the city-state). Austin's conclusion nevertheless ends on an optimistic note, wagering that China's leadership will have opted for wise solutions by 2025.

The book contains a chronology, a table of abbreviations, a selected bibliography, and an index, all of which make for a veritable introductory manual on China's digital policy that is accessible and easy to use.

However, I remain perplexed over the general argument put forward in the first chapter to justify the book's structure. As it focuses on the Chinese leadership's ethical choices and values in the area of the information society, Austin has decided to deal with the subject in a normative manner, evaluating at the end of each chapter the Chinese strategy in light of "nine ideal values for information society policy" (p. 9). These values are divided into three groups: first, "national information ecosystem," which includes freedom of information exchange, protection of information exchange, and trusted information; second, "an innovative information economy," including "transformation intent," an innovation system, and the existence of an innovative class; and finally, a "global information ecosystem" covering the notion of strategic stability, the need to bridge military divides, and the need for an interdependent informatised security (p. 16). Even if inspired by international works and reports, these nine values seem to have been chosen arbitrarily. They add nothing to analyses of the Chinese leadership's dilemmas, which have been very well dealt with in the book. Therefore, this approach seems to be quite superfluous in a book that otherwise contains a clear and sufficiently complete synthesis of China's digital policy.

\section{Translated by N. Jayaram.}

I Séverine Arsène is a researcher at CEFC and Chief Editor of China Perspectives (sarsene@cefc.com.hk).

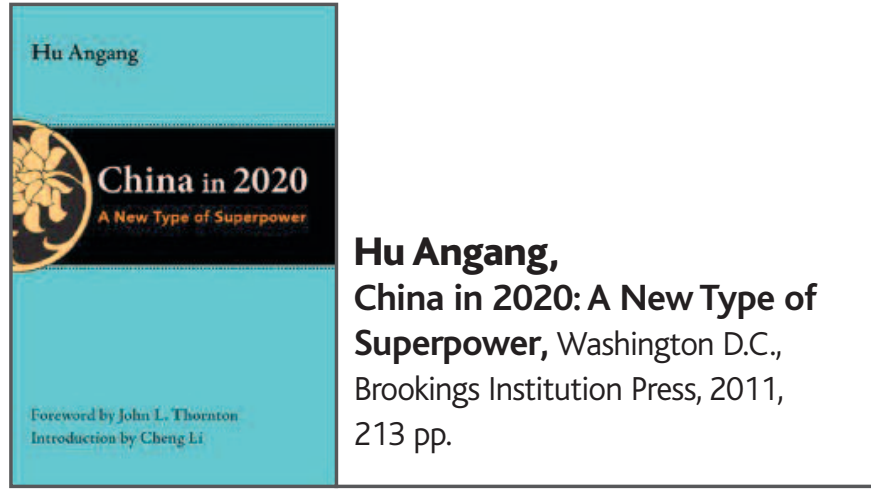

\section{MAOLIANG BU}

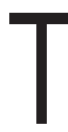
he economic rise of China has not only inspired new books on how to understand China's economy and its influence on the rest of world, but has also been accompanied by pessimistic views on China's impending collapse. A recent example is David Shambaugh's article "The Coming Chinese Crackup," published in The Wall Street Journal. Given that these books and views are fairly mixed and mainly published by non-Chinese scholars, it is of increasing importance to explore the perspectives and hear the voices of native Chinese scholars. Hu Angang's book China in 2020 serves this aim well. As mentioned in the introduction by Dr. Cheng Li," (...) arguably no scholar in the PRC has been more visionary in forecasting China's ascent to superpower status, more articulate in addressing the daunting demographic challenges that the country faces, or more prolific in proposing policy initiatives designed to advance an innovative and sustainable economic development strategy than Hu Angang."

China in 2020 covers two themes of particular interest: Chinese optimism and exceptionalism. Hu has been consistently optimistic about China's socioeconomic transformation. He declares that if current development trends continue, the day when China overtakes the U.S. in a variety of respects not only in economic power but also in human capital, science, and technology - is not far off. The sources of his confidence in China becoming a superpower are detailed in different chapters of the book: economic power (Chapter 2), human resources and capital (chapters 3 to 5), science and technology achievements (Chapter 6 ), and the ability to address climate change (Chapter 7). All of these optimistic assessments are supported and explained by a wealth of information and statistics, in the accessing and collecting of which Hu has an incomparable advantage and rich experience. Hu founded and leads the Center for China Studies at Tsinghua University, which has carried out considerable work on China's national reports (guoqing baogao) covering various social and economic aspects over the long term (since 1998). More importantly, Hu's confident optimism regarding China is built upon a deep understanding of the patterns and efficiency of China's resource allocation, often covered by eyeball-catching topics that are overlooked by observers both inside and outside of China.

As for the second theme, it is widely acknowledged that an emerging superpower will destabilise the existing international system. However, $\mathrm{Hu}$ points out that China's rise to superpower status will be an exception, which he names a "new type of superpower." He believes that China has neither the resources nor the intention to replace the U.S. and become sole leader of the world within the waves of globalisation. On the contrary, China needs to cooperate with the U.S. in order to meet global challenges. Furthermore, the book covers a great deal of the thinking behind China taking more re- 
sponsibility and making greater contributions to international society in terms of economic development, as well as culture, science, and ecology. Hu's view of Chinese exceptionalism will no doubt encounter continued scrutiny. However, one more interesting issue regarding this "exceptionalism" is that it represents the view of a significant portion of China's mainstream intellectuals. In contrast to individual scholars with sharp and independent opinions, these mainstream intellectuals serve more as volunteer expounders of China's story to the rest of the world in a pleasing way with persuasive data and up-to-date descriptions of national strategies. Hu's book is a good example of these writings, and provides an opportunity to acquire a more nuanced and balanced understanding of influential Chinese scholars.

It should also be noticed that an insider's view does not necessary mean lack of criticism. In fact, Hu Angang has raised many frank suggestion and comments that have been effectively adopted by senior government leaders. However, non-Chinese readers may find difficult to understand this type of criticism. The difficulty does not lie in linguistic translation, but in an adequate understanding of the Chinese system, which again demands an insider's view. Nevertheless, the views of Chinese insiders are receiving increased attention, as evidenced by the 2015 May/June issue of Foreign Affairs (entitled Embracing China's "New Normal": Why the Economy Is Still on Track), which unprecedentedly published several articles by Chinese scholars, including Hu Angang.

My concern about this book is that Hu's approach takes the perspective of cooperative rather than non-cooperative game theory. Both of his two main views of Chinese optimism and exceptionalism would be more convincing if taking account of a non-cooperative reaction from the rest of world. As for optimism, whether China can become a superpower will depend not only on China itself but also on how the rest of world responds to it. Similar logic can be found in the development of trade theory, which already shows that the large country model is very different from the small country model. As for exceptionalism, there is a need for non-cooperative analysis to anticipate how China would respond to non-cooperative actions by other countries against China's development in a dynamic model setting. Furthermore, can China remain exceptional in terms of taking more cooperative action? The answers to these questions are not discussed sufficiently in the book.

The opinions and ideas of Chinese authors have long been inaccessible to non-Chinese speakers. Some Western readers may be tired of outsiders' views and increasingly interested in works by insiders. The Brookings Institution Press, and particularly Dr. Cheng Li, have done a great service in creating the Thornton Center Chinese Thinkers book series. If you would like to learn more about the views of a leading proponent of Chinese optimism and exceptionalism, you should definitely not miss Hu Angang's book, China in 2020 .

Maoliang Bu is an associate professor of economics at Nanjing University, and an adjunct professor of international economics at the Hopkins-Nanjing Center. He is a 2015-2016 Alexander von Humboldt Foundation Fellow at the Chair of China Business and Economics at the University of Würzburg, Germany (bumaoliang@gmail.com).

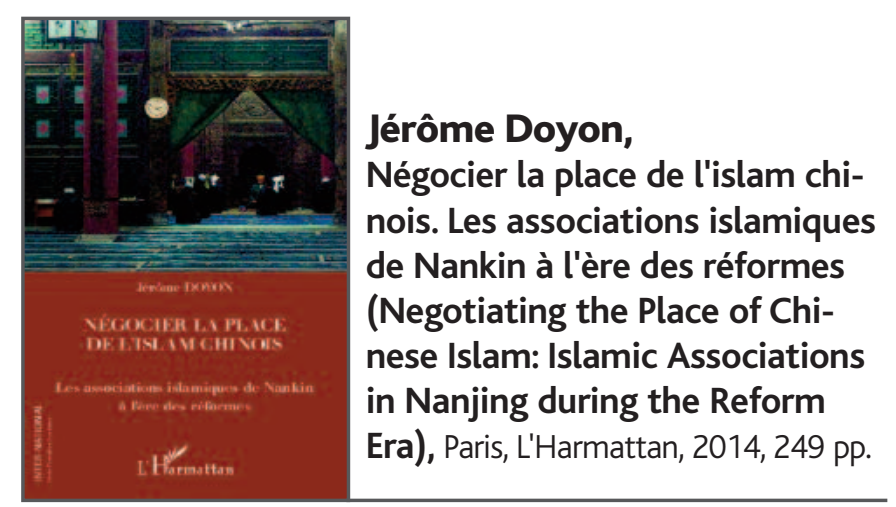

\section{RÉMI CASTETS}

1 his book is the result of research conducted by Jérôme Doyon for his Master's thesis. The young scholar, currently pursuing his doctorate, carried out expert field work in early 2011 in Nanjing municipality. The author chose to focus on the role, functioning, and interactions of local branches of the Islamic Association of China (IAC) in Nanjing (IAN) and Jiangsu (IAJ). He starts off with the observation that the Chinese state's control over its Muslim populations operates in the special contexts of each region and leads to diverse configurations. This original monograph adopts a "micro" analysis framework, making a break with the top-down approaches often pursued in the study of state control measures relating to religion. The information collected by the author helps reconstitute, based on recontextualised subjectivities, the ways of functioning of the IAC's local branches and the challenges they face.

It is rare to come across Western scholars' work regarding the complex mechanisms of interactions among believers, different strata and compartments of the Chinese administration, and the IAC. This is a sensitive subject especially in areas with Muslim majorities in the northwest of China. The author opportunely explored a much less sensitive context in Nanjing by interviewing academics, clerics, the laity, IAC members, and officials.

The book's interest lies in taking the reader into the lives of the IAC's branches in Jiangsu. Doyon sheds light on the motivations of their officials and interlocutors (the local and central administration, the Communist Party, local laity, and those from other provinces) and presents a broad picture of the constraints and resources they deal with. The finesse of his analysis lies as much in his reliance on solid knowledge of conceptual frameworks of social sciences as of works published in recent years on the oversight of religion in China.

In the first chapter, Doyon notes the IAC's role in the management of religious sites in Nanjing, evaluating to what extent it forms part of the continuities of associations that preceded it, as well as the extent to which it departs from them. He mentions the specificities of the local context: ethnic and sectarian homogeneity, the IAN's financial resources, and absence of political conflict or financial disputes with the administration, etc. This context explains to a great extent the modes of control and financial management adopted by the IAN and IAJ. Given the meagre potential for financing of the small local Muslim community and of funding being linked to income from the IAN property and governmental connections, the IAN has acquired a major degree of control over the finances and activities of local religious sites. It is worth noting that the IAN and IAJ face less pressure from the state and enjoy greater elbow room given the relaxed local political context. 